\title{
Medicine and Human Rights
}

Cleveringa Inaugural Oration

Leiden, The Netherlands

November 26, 1998

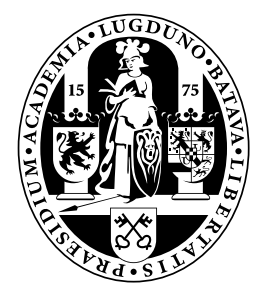

Universiteit Leiden 
Meneer de Rector Magnificus, zeer gewaarderde toehoorders

\section{November 26, 1940}

On November 26, 1940, the noted jurist Professor E.M. Meijers of the Faculty of Law at the University of Leiden, was barred from giving his scheduled lecture at the University. On that day, as part of a series of anti-Jewish measures imposed by the Nazi occupation forces in the Netherlands, all 2500 Jews who were members of the Civil Service of the Netherlands were dismissed. Among those expelled from their posts were the Chief Justice of the Supreme Court of the Netherlands and forty-one university professors, including Professor Meijers.[1]

Professor Rudolph Pabus Cleveringa, Dean of the Faculty of Law at the University and an authority on civil and international law, spoke in place of Professor Meijers. In his speech in the packed Great Auditorium of the University, Dean Cleveringa came to the support of his colleague and declared that the Nazis were violating international law. "Their actions are beneath contempt," he declared. His words were greeted by thunderous applause. One of the students in the auditorium remembered 20 years later what happened after Dean Cleveringa had finished: "There were a few moments of silence and then suddenly, without previous arrangement, we started to sing the national anthem. There were few of us who could hold back our tears." Copies of Dean Cleveringa's address were distributed throughout the Netherlands, so thousands were able to read the full text within a few days. Dean Cleveringa was imprisoned by the Nazis two days later.[2]

At the same time as Dean Cleveringa's speech, Professor J.A.J. Barge, Professor of Anatomy and Embryology in the Faculty of Medicine, was scheduled to give the twelfth in a series of lectures on physical anthropology in the Anatomical Laboratory of the University. Professor Barge, a noted authority on the races of humankind, in his lecture refuted on scientific grounds the Nazi racial theories and the Nazi concept of an Aryan "super-race". Professor W. Hijmans, who attended the lecture as a medical student, recalls that Professor Barge made very clear his sharp rejection of the racist views of the Nazi occupiers.[3]

Later that same day Professor E.J. van Holk, Professor of Theology at the University, gave a scheduled lecture on philosophical ethics. He entreated his 
students on ethical grounds not to abandon the victims of the Nazi actions. His lecture that afternoon, one of a series on the stoic philosophers, included a discussion of the work of Baruch de Spinoza, the 16th-century Jewish philosopher whose family had found refuge in the Netherlands.[4]

Students at the University of Leiden, like students at the University of Delft, responded to the Nazi measures by initiating a strike; classes were suspended and at Leiden continued to be suspended for the duration of the war. Professors Cleveringa, Barge and van Holk may not have been the only ones who spoke out on that memorable day. The official history of the University of Leiden for that period mentions the probability that other professors also showed their disapproval of the Nazi measures, but their names have not been recorded.[5] What is known, however, is that a number of Leiden professors, such as Professor Telders of the Faculty of Law, and a number of students, including a leader of the Leiden student resistance, Johannes Mulders, lost their lives during the Nazi occupation.

\section{The Cleveringa Professorship}

Thus, on November 26, 1940, a courageous lawyer stated the importance of allegiance to justice, a courageous physician stated the importance of allegiance to science, and a courageous theologian stated the importance of allegiance to ethics, even under circumstances in which allegiance to justice, science and ethics carry great risks. The issues these three speakers emphasized have increased in importance in the half-century that has followed. Lawyers have increasingly become concerned with protection of human rights and with what has been termed "international humanitarian law," both within nations and internationally. Physicians have increasingly become concerned with protection of the rights to health and to health care and with protection of other human rights, both within nations and internationally. Philosophers and ethicists have increasingly become concerned with the ethical, theological and philosophical roots of protection of human rights and have emphasized the fact that Spinoza, a generation before the work of John Locke, taught that freedom to think and to speak is fundamental to the stability and the progress of a democratic society.

It is of profound relevance, and particularly to me as a foreigner, that these three great traditions came together within the course of a few hours on the campus of a great university in a historic city in an extraordinary nation. The 
University, founded in 1575 in recognition of the City's resistance to Spain, bears the motto, "Praesidium Libertatis" (Bulwark of Liberty). The City of Leiden justly prides itself on its history of hospitality to victims of persecution. Of special interest to a visitor from the United States who received his medical education in Massachusetts, the exiles included Puritans who found a temporary haven in Leiden in 1609 on their way from escape from persecution in England to the founding of Plymouth Colony in the New World. The Netherlands has a long history of admitting refugees, as exemplified by the acceptance into full citizenship of Jewish refugees from Spain and Portugal that included the family of Baruch de Spinoza, of supporting the free exchange of ideas and of supporting international efforts to support the creation of a just, stable and peaceful world. This nation is the host in the Hague to the International Court of Justice and to the Organization for the Prohibition of Chemical Weapons. The Netherlands was host to the Hague Peace Conference in 1899 and will be host to the Hague Appeal for Peace Conference in 1999. Perhaps most important, the Netherlands has led the nations of the world in providing economic development aid to poor nations.

The Cleveringa Chair was created by the University of Leiden in 1970. The Chair has been filled through an annual one-year appointment by the University Board, usually in the Faculty of Law. The occupant of the Cleveringa Chair for 1998-99 has for the first time been appointed in the Leiden University Medical Center. The University Board specified that for this year the occupant of the Chair, which will have a University-wide character, should concentrate on "justice, freedom and responsibility, especially regarding medicine and human rights." It is a special privilege to be invited to be the occupant of this Chair, to give this Oration and to teach on medicine and human rights in this nation, in this city and at this university. I am grateful to the University Board and to the Dean and other members of the Board of the Leiden University Medical Center for this privilege and for the opportunity to pay homage to Professors Cleveringa, Barge and van Holk and to all the others in the Netherlands and throughout the world who showed great courage in a terrible time.

\section{The Right to Health}

Law, ethics and medicine, as well as many other sectors of society, have essential roles to play in the protection of human rights. The importance of the first two has been discussed by previous Cleveringa Professors, but the 
importance of medicine in the protection of human rights requires more extensive discussion today.

The task of medicine and of those who labor in its vineyards must be the promotion and protection of health in its broadest sense. In the words of the Preamble to the Constitution of the World health Organization, "Health is a state of complete physical, mental and social well being and not merely the absence of disease or infirmity." Promotion and protection of human rights, I will argue in this address, is an essential element in the promotion and protection of health.

The Preamble to the Constitution of the World health Organization goes on to say that "The attainment of the highest possible level of health is a fundamental human right."'[6] Protection of the right to health demands a number of actions, including elimination of threats to health caused by racism, sexism, ageism, homophobia and poverty, removal of barriers to equitable access to meeting basic needs such as those for education, housing, nutrition, public health and medical care, special protection of vulnerable populations, commitment to sustainable development and environmental protection, and protection from the unwanted risks of research.[7]

\section{Elimination of Barriers to Health Caused By Bigotry and Poverty}

Almost 60 years after Professor Barge's lecture, racism and other of bigotry remain barriers to the promotion and protection of health. There is ample evidence that bigotry continues to exist in many countries of the world and may in some nations be increasing as groups such as immigrants are being "demonized."'8] The Neo-Nazi movement in Europe is one example. In the United States pseudo-scientific attempts, such as those in Hernnstein and Murray's book, The Bell Curve, are being made to justify racism and efforts to remedy the consequences of racism and sexism, such as "affirmative action," are being curtailed.[9]. Discrimination against minority groups results in higher incidence and prevalence of illness and disability not only through denial of access to medical care and lower quality of care, but also through denial of equitable opportunities in housing, education and employment and in access to other services and benefits.

While there are indeed some illnesses, such as sickle cell anemia, that are statistically associated with other inherited characteristics such as skin color, for the most part the differences in health seen between groups of people char- 
acterized by their "race" are determined by the social conditions imposed upon them. An important example is infant mortality in the United States, which for babies characterized as "Black" is twice as high as the rate for babies characterized as "White". There is a vast amount of evidence that most of this difference in health status associated statistically with race, as well as other differences in health status, is caused by differences in social class, income, education, employment status, and other "risk factors" and by differences in access to medical care.[10] Many of these differences in social conditions and in access to and quality of medical care are caused by "racism," discrimination against individuals and groups of people based on skin color and of other perceptions of their "race." Some public health activists in the United States have even argued that the use of "race" in public health statistics should be abandoned.[11] Victimization by other forms of bigotry, such as sexism, ageism, and homophobia, also appear to be associated with poor health.

The increasing gap between rich and poor - among countries and within countries - is an extremely important barrier to health. The gap in income, and especially in wealth, in the United States has increased sharply in the years since 1980, in part due to the replacement of higher-wage jobs by lowerwage jobs and in part by an increasingly regressive tax structure.[12]

The 1998 Human Development Report, published by the United Nations Development Program, provides dramatic evidence of the international aspects of the increasing gap. The richest fifth of the world's people consume 86 percent of all goods and services; the poorest fifth consume just 1.3 percent. The world's 225 richest individuals have a combined wealth of over one trillion dollars, equal to the annual income of the poorest 47 percent of the world's population. Of the 4.4 billion people living in "developing countries," nearly three-fifths lack access to safe sewers, a third have no access to clean water, a quarter do not have adequate housing and a fifth have no access to modern health services of any kind. It is estimated that the additional cost of achieving and maintaining universal access to basic education and basic health care, reproductive health care for all women and adequate food, clean water and safe sewers for all is roughly $\$ 40$ billion a year, less than four percent of the combined wealth of the 225 richest people in the world.[13]

In the name of "economic development" a number of international and national policies have led to an increase in the grossly uneven distribution of income, with ever growing numbers of people living in poverty as well as in 
increasing depths of poverty. "Structural adjustment" policies, foisted upon poor countries by the World Bank and other international financial institutions, force cuts in budget for educational, human and health services. Over the past decade the net flow of resources has shifted, and wealth now flows largely from poor countries to rich countries. "Globalization" often increases levels of poverty and results, more often than not, in the neglect of government-funded social programs and regulations concerned with protecting the environment.[14]

Carrying charges and repayment of overwhelming debt cripple the economies of poor countries and threaten the health of their peoples by limiting governmental expenditure on services and by undermining development. A large proportion of the limited foreign exchange income of poor nations is used to make interest payments on their external debt. The debt crisis is deepening, its impact on government expenditures for human services is intensifying, and the Heavily Indebted Poor Countries Initiative, launched with such great optimism in 1996, has largely failed to make significant progress in reducing the debt.[15]

The United Nations has set as a goal for each rich country of the world to provide 0.7 percent of their gross national product (GNP) as annual foreign aid contributions to poor nations. Instead, overall official development assistance levels have fallen to their lowest level since 1973, and now average just 0.33 percent of GNP. The steepest decline occurred in the United States, where official development assistance was reduced from 0.56 percent of GNP in 1960 to 0.12 percent in 1996. Among the exemplary exceptions to the unwillingness of the world's industrialized nations to provide 0.7 percent of their GNP as aid is the Netherlands which, along with Norway and Sweden, regularly provides close to one percent of its GNP in governmental aid.[16]

Health workers can make a major contribution in their own countries and in the world to alleviation of bigotry and of poverty. Work against bigotry requires efforts, both nationally and internationally, to combat the demonization of those seen as different and threatening.

Internationally, increased efforts are required in order to end protectionist barriers and other impediments against trade and development that maintain poverty in less developed countries; to distribute world resources equitably; to promote cancellation of Third World debt without the conditions imposed by structural adjustment programs; and to invest in programs such as health ser- 
vices and education, especially in rural areas. Work to end poverty within nations includes support of programs that guarantee full employment, that protect the safety net for those for those without jobs or with jobs that fail to provide adequate income, and that lead to enactment of steeply-progressive income taxation and inheritance taxation to reduce the gap between rich and poor. In the United States, where attempts are being made to reduce progressive taxation and where the safety net in place since the 1930s was destroyed by welfare repeal legislation in 1996, these efforts are especially important.

\section{Access to Basic Services and to Medical Care.}

Access to basic services, such as education, housing, nutrition, and public health, and to medical care of the highest quality attainable, is extremely important in the protection of health. Although level of education, for example, is one of the strongest predictors of health status and of well-being, worldwide more than 900 million adults are illiterate, two-thirds of whom are women, and more than 300 million children are not in primary or secondary school.[17] Public health services are essential to the maintenance of health. In many countries of the world public health services are desperately underfunded. Even in the United States, a rich country, there is clear evidence of gross neglect of public health services.[18]

Medical care is one of the essential elements in the protection of health and in the treatment and rehabilitation of the sick. Throughout the world, in countries rich and poor, many people have no access to basic medical care. Some people have no access to care because they lack the resources to purchase it and the state does not provide it, others lack access because services are not available in their communities, and others lack access because of discrimination on the basis of their poverty, caste, race, or status as prisoners, detainees, refugees, or undocumented or even documented immigrants. In the United States, some 43 million people, 16 percent of the population, totally lack insurance coverage against the cost of medical care services and it is estimated that 50 million more are grossly underinsured.[19]

Discriminatory practices not only deny people access to care but may also relegate others to inferior care. Failure to respect dignity in medical care settings has stigmatized people with conditions such as HIV/AIDS or those with mental or physical disabilities and has resulted in denial of appropriate treatment or their being subjected to inappropriate clinical interventions.[20] In the 
United States, there is increasing evidence that the quality of care for minority groups is often lower than for others.[21] Minority physicians, who are much more likely to care for minority people than are other physicians, are still grossly under-represented. Current attacks on "affirmative action" programs in the United States, such as the recent decisions in the States of California and Washington to end their programs, are likely to exacerbate this problem.[22]

Health professionals can have direct impact on the equitable provision of medical care services. This involves not only efforts to provide services wherever they are most needed in their own nations, but also efforts to support the work of the World Health Organization and of non-governmental organizations such as the Doctors of the World and Doctors Without Borders.[23] Physicians can also do more to educate medical students and other physicians on sensitivity to the needs of those being discriminated against.[24] They can also exert significant influence, through local community action and through political action, on provision of universal coverage for medical care services and on lowering the barriers to access to other human services.

\section{Special Protection for Women and Children}

In many countries, women are denied full participation in society and the protection of basic rights. More than two-thirds of the 900 million illiterate adults in the world are women. Women work more than two-thirds of the world's working hours, yet they earn less than ten percent of the world's income and own less than one percent of the world's property.[25] Practices harmful to their health, such as genital mutilation, are in some communities carried out to further social policies or cultural traditions.[26]

Violations of human rights exist in the design and implementation of health policies. For example, population policies that fail to respect the conditions necessary for individual decision-making may be less effective than those that respect autonomy. In the past few decades, governments and international agencies have increasingly recognized that women must be able to make and effectuate free and informed choices about reproduction. Yet these choices are limited in the design of health policies, as well as in their implementation. The promotion and protection of rights to education, information, privacy, and equal rights in marriage and divorce are necessary if population policies are to be successful.[27] 
In addition, the rights of children are often violated. The State of the World's Children, the annual publication of the United Nations Children's Fund, highlights the horrendous problems faced by children in developing countries. The 1996 edition was devoted to the special impact of war on children, to be covered later in this address.[28] The 1998 edition presents material on child nutrition. Over 200 million children in developing countries suffer from malnutrition, which is a major factor in more than half of the annual 12 million deaths among children under the age of five. Malnourished children who survive are more likely to grow up with lasting mental or physical disabilities.[29]

Furthermore, more than 300 million children are not attending primary or secondary school. Children in many countries of the world are forced to work under brutal, unhealthy and unsafe conditions and while being denied an education.[30]

\section{Sustainable Development and Environmental Protection}

Prevention of despoilment of the physical environment and mitigation of environmental hazards where they exist are important factors in sustainable development and in the prevention of illness. Hazardous physical environments contribute to human illness, adverse psychosocial effects, economic disincentives, decay of infrastructure, and community disintegration.[31]

The 20 percent of the world's population living in the world's richest countries account for almost 90 percent of the world's private consumption.[32] The United States and other industrialized countries have since 1950 produced 76 percent of the world's cumulative carbon emissions from the burning of fossil fuels. Global carbon emissions increased from 1.3 billion tons in 1980 to 6.2 billion tons in 1996. Carbon dioxide, formed from carbon emissions in the atmosphere, is the most important "greenhouse gas" - which causes "global warming" - produced by human activities. Despite the 1992 climate change treaty in which the industrialized countries agreed to voluntarily hold emissions to 1990 levels by the year 2000, these nations increased the emissions. For example, Japan increased its emissions from 1990 to 1996 by 12.5 percent, Australia by 9.6 percent, and the United States by 8.8 percent.[33]

Increased illness and death, it has been predicted, will result from global 
warming-produced heat waves, air pollution, increased outbreaks of mosquitoborn and water-born diseases, decreased availability of drinking water and diminution in food production and in ecological-life support systems.[34] Yet despite this forecast, industrialized countries gathered together at the Climate Change Meetings in Kyoto, Japan in 1997, and in particular the United States, were unwilling to pledge to reduce greenhouse gas emissions sufficiently to decrease the rise in global warming or to permit developing countries to increase their emissions sufficiently to allow adequate economic development.[35]

The physical environment was the major topic at the United Nations Conference on Environment and Development and the "Earth Summit" held in Rio de Janeiro in 1992. The participants adopted a program of action known as Agenda 21 which established as a goal the protection of the Earth's environment through sustainable development and through curtailment of activities that cause major environmental degradation. In the Review Conference held five years later at the United Nations Headquarters in New York City, the progress in implementation of Agenda 21 was reviewed. During the five years since 1992, annual emissions of carbon, which produce carbon dioxide, the leading greenhouse gas, had climbed to new highs, altering the composition of the atmosphere and changing the earth's heat balance. During these five years, the biological riches of the planet had been rapidly and irreversibly diminished. Huge areas of old-growth forests had been degraded or cleared - in temperate as well as tropical regions - eliminating thousands of species of plants and animals. Biologically rich wetlands and coral reefs were destroyed. It has been estimated that the total cost of implementing Agenda 21 would be approximately $\$ 600$ billion per year, yet these resources have not been forthcoming.[36]

An especially egregious violation of denial of rights, often termed "environmental injustice," occurs when the areas inhabited by the poor or minority groups discriminated against within a society are those which are also most polluted.[37] In the United States, there is clear evidence of selective pollution of areas in which poor people or people of color live, often termed "environmental injustice". Serious health-related inequities have been documented with respect to lead poisoning, proximity to noxious facilities, distribution of air pollution, exposure to health and safety hazards at work, consumption of contaminated fish, location of municipal landfills and incinerators, location of abandoned toxic waste dumps.[38] 
The environment must be protected from further degradation. Eight nations - the United States, Russia, Japan, Germany, China, India, Indonesia and Brazil - are disproportionately responsible for degrading the environment in which their neighbors live. The recent forest fires in Indonesia are an example of irresponsible management of resources that led to degradation of the environment of the entire global region. Sustainable development should be globally redefined by specifying agreed-upon limits to critical resource consumption. These limits should be politically established and based on equal rights to the consumption of resources on a global per capita basis both within and between nations. To end military degradation of the environment, discussed later in this lecture, clear targets must be set for conversion of the resources used by the military to productive purposes and for conversion of military programs to programs fostering human development, environmental clean up, health and peace.[39]

\section{Protection From Research Risks}

The human rights violations perpetrated by the Nazis in their medical experiments that were the subject of the Nuremberg "medical trials," and the Nuremberg Code that emanated from the trials, have been extensively reported.[40] Although there has been considerable progress in the regulation of human research over the past 50 years, contemporary medical research studies may still in some instances lack adequate informed consent procedures and the risks to the study population may still be disproportionate to the societal benefits. Some members of the medical research community may continue to use disenfranchised and vulnerable populations for human experimentation.

In the United States the long-term observation, without definitive treatment when it became available, of black men with syphilis in the southern part of the country are a well-known example of discriminatory selection of subjects for research and of failure to keep subjects appropriately informed of their options for treatment, even after effective treatment became available. Much of the suspicion that members of the African-American community in the United States have of medical care services has its roots in this and other discriminatory practices.[41] Furthermore, unethical experimentation, as we will note, is often associated with war or preparation for war in the name of "national security." [42] Health professionals have a responsibility, in the interest of both human rights and health, to make certain that the provisions of the 
Nuremberg Code and of more recent requirements for free and informed consent are universally observed.

\section{The Right to Peace}

In 1981 the World Health Assembly adopted the following resolution (WHA 34.38): "The role of physicians and other health workers in the preservation and promotion of peace is the most significant factor for attainment of health for all.’[43]

\section{Freedom from violent conflict}

Many people of the world are involved in violent conflicts over which they have no control. The 20th century has been the bloodiest in human history, with an estimated 250 wars, more than 110 million people killed, countless people wounded and at the very least 50 million refugees. Over the 50 years since the end of World War II, nuclear weapons have not been used in war and there is no clear evidence that biological weapons have been used; chemical weapons have been rarely used. On the other hand, "conventional weapons" have since 1945 directly caused the deaths of more than 30 million. It is estimated that during World War I civilian deaths accounted for 14 percent of all deaths, during World War II 67 percent of all deaths, and during the 1980's about 75 percent of all deaths.[44] In the 1990's, since the end of the Cold War, violent conflict has claimed the lives of some 4 million people and the percentage of these deaths that are civilian deaths is estimated at 90 percent, many of them children.[45] Many millions more civilians have died from warrelated hunger and disease as agriculture and the economy were destroyed. In 1997 more than 35 million people were refugees or internally displaced as a result of violent conflict and were forced to live in conditions contributing to spread of disease, malnutrition, and early death.[46] Moreover, these conflicts are often characterized by rampant and gross disrespect for the principle of medical neutrality and of the Geneva Conventions, which guarantee the provision of health care without discrimination to all injured and sick combatants and civilians during periods of conflict.[47]

War, preparation for war, and militarism lead directly to additional abuses of human rights that represent dangers to health. Denial of freedom of expression and suppression of the independence of health workers and the voices of medical and public health officials is more likely to occur during war or civil 
conflict. This alone can have deleterious effects on health because it compromises the ability to contain the spread of disease, sustain vaccination and immunization programs, address humanitarian emergencies, raise alarms about environmental threats to health, and put into place effective health policies and programs that reach all members of affected populations.[48] As we have noted, unethical human experimentation may be performed in the name of "national security."

Military activities also threaten development and the achievement of a better standard of living. The nations of the world divert extraordinary resources - approximately $\$ 800$ billion annually - to war and preparation for war. It has recently been estimated that the cost of the U.S. nuclear weapons program have been at least $\$ 5.5$ trillion since 1940 , constituting 10 percent of all federal budgets in that half century.[49] Even wealthy countries, such as the United States, suffer the consequences of diversion of resources to military purposes. Developing countries are the most affected, however, suffering delay or reversal of economic development and deprivation of essential nutrition, housing, education and health services. As Dwight Eisenhower, who ha $\mathrm{d}$ been elected President of the United States, said in 1953, "Every gun that is made, every warship launched, every rocket fired signifies, in the final sense, a theft from those who hunger and are not fed, those who are cold and are not clothed. The world in arms is not spending money alone. It is spending the sweat of its laborers, the genius of its scientists, the hopes of its children..."

If significant portions of military expenditures are not reallocated to promote health and social well-being, the aims of sustainable development and environmental protection cannot be reached. All nations, especially the United States which spends $40 \%$ of the world's military expenditures, should reduce its military expenditures in inflation-corrected funds by at least ten percent per year over the next 5 years and use the funds to alleviate poverty and improve social and health programs within their own societies and to provide aid to poor nations.[50]

Military activities are a major cause of devastation to the environment, not only during war but also before and after war. Examples include the devastation caused during the Indo-China War by bombing, mechanized land clearing, napalming, and herbicide-induced defoliation, and the environmental consequences of the Persian Gulf War. Atmospheric nuclear tests by the United States and the Soviet Union in the 1950s and early 1960s produced 
worldwide radioactive fallout. Even after the tests were moved underground, radioactive pollution continued to occur through venting into the atmosphere, or through the deposition of long-lived radio-nuclides underground. In addition, storage of large quantities of plutonium, which has a radioactive half-life of thousands of years, presents hazards of leakage in the ecosystem. Nonnuclear weapons also cause enormous pollution during their life-cycle. They generate large amounts of toxic chemicals, including cyanides, pesticides, PCB phenols and heavy metals. The U.S. alone generates 400,000-500,000 tons of military toxic waste annually, not including nuclear waste.[51]

The leading merchants of death, the six leaders in arms sales to the world, are the five permanent members of the United Nations Security Council - the United States, United Kingdom, France, Russia, and China - and Germany.[52] Proposals to end the international arms trade include the International Code of Conduct on Arms Transfers and a Draft Convention on the Monitoring and Reduction of Arms Transfers, Stockpiling and Production. The convention incorporates the concepts of "territorial" (also known as "nonprovocative" or "confidence-building") defense, economic conversion and alternative security. It moves beyond the current system of voluntary registration of arms transfers to mandatory registration, bans offensive military capacity and lays the foundation for an international system for global security.[53] The ultimate aim, must be disarmament to a level of arms that will permit no more than "territorial defuse" or "defensive defense." To ensure this, nations must further develop instruments of peaceful resolution of conflicts, such as confidence-building measures and dialogue, and implement a strict code of conduct not to export arms to countries in conflict regions, countries which violate the human rights of their people, and countries in which governments or non-government militias recruit or abduct children for use as soldiers. Health workers should also support proposals to declare illegal under international humanitarian law the use of weapons that cause "superfluous injury or unnecessary suffering."[54]

Health professionals have played an important role in conflict resolution and mediation. Training for non-violent conflict resolution and mediation should be introduced as elements of the curriculum in medical education and indeed at all levels of education.[55]

The work of the United Nations in peace-making and peace-keeping must be supported. The United Nations is the only existing international body that 
can organize such efforts. The United States, which is 1.5 billion dollars in arrears in its dues to the United Nations, and other nations that do not pay their United Nations dues should be urged to do so in full and on time.[56]

A just and peaceful international order also requires respect for the rule of law both within nations and among nations. The agreement in Rome in 1998 to establish a permanent International Criminal Court was an important step in this direction. It provides for an independent prosecutor who will be able to act upon allegations received from the public and covers genocide, crimes against humanity, and war crimes and aggression; there are provisions to protect the rights of victims and witnesses.[57]

\section{Freedom From War-Related Torture}

Torture, which has been documented in recent years in more than 100 countries around the world, is more likely to be carried out during war or civil conflict. Torture, as is well known, causes acute trauma and long-lasting physical or psychological suffering to survivors, their loved ones, and society at large.[58] Physicians and other health workers become complicit in torture when they certify individuals as able to withstand torture or falsify or fail to report evidence of torture in detention facilities.[59]

Physicians, psychologists and forensic pathologists have been at the forefront of efforts to document and expose torture, and their work has led to the emergence of treatment and prevention programs throughout the world. This work must be continued and strengthened.[60] Survivors of trauma from displacement, torture, and war often receive insufficient help in coping with the physical and psychological effects of these traumas. Health professionals must not only work to prevent torture but also help to provide adequate services for the victims.[61]

\section{Freedom From War-Related Rape and Genocide}

Recent years have also seen, particularly in Bosnia and Hercegovina, the use of rape as a weapon of war. While rape has always been associated with war, it is now being used to cause pregnancy and therefore as an instrument of genocide. There have been recent efforts to declare rape a war crime, but arrest and prosecution of the perpetrators has so far been extremely difficult. This work must be continued and expanded. Health workers also have special responsibility to work for the arrest and prosecution of those who permit or 
perform rape during war The International Criminal Court, the structure of which was recently negotiated in Rome, must be supported and strengthened.[62]

\section{Freedom From Weapons of Mass Destruction}

The right to life and health is threatened by the existence and active deployment of nuclear, chemical and biological weapons, and anti-personnel landmines.[63] Nuclear weapons are the most destructive weapons ever devised. Despite some limited reductions in nuclear forces, approximately 35,000 nuclear warheads still remain in the world's nuclear arsenals, with a destructive power estimated at about 8 billion tons of TNT, equal to almost 1.5 tons of TNT for every human being on the planet. Many of these weapons remain on hair-trigger alert and pose a risk of accidental as well as purposeful detonation.[64] Both "vertical" proliferation (additions to the stockpiles of nations that now possess these weapons) and "horizontal" proliferation (spread of the weapons to nations that do not now possess them) continue. Examples of "vertical" proliferation include the development of "improved" weapons using subcritical tests and computer simulation (tests not prohibited by the Comprehensive Nuclear Test Ban Treaty (NPT)). Examples of "horizontal" proliferation include the recent tests of nuclear weapons by India and Pakistan.[65]

The development, production, testing, stockpiling, transfer and use of chemical weapons was outlawed by the Chemical Weapons Convention (CWC) of 1993, which entered into force in 1997, but the nations of the world that possess chemical weapons and are required to destroy them by the CWC have only just begun to do so. The Organization for the Prohibition of Chemical Weapons, recently established in The Hague, is charged with the responsibility of ensuring that this is done. Although there has been no proven use of these weapons since they were used in the Iran-Iraq War and against the Kurdish village of Halabja during the 1980s. The use by a sect in Japan of chemical weapons to attack people in the Tokyo subway system illustrates the continuing risk of use of these weapons, not only by nations but by individuals and by groups.[66] Stockpiles of biological weapons are believed to continue to exist despite their being outlawed by the Biological Weapons Convention (CWC) of 1971, which entered into force in 1974. There is clear evidence that biological agents were produced by a number of nations and may have been weaponized by Iraq during the period leading up to the Gulf War.[67] 
Life and health are jeopardized daily by anti-personnel landmines, which kill and maim indiscriminately, and continue to do so for decades after the cessation of a conflict. It is estimated that worldwide there are more than 110 million mines scattered and another 100-150 million in stockpiles. Every month more than 2000 people are killed or disabled by landmines. As a result of a campaign waged worldwide by non-governmental organizations, for which the 1997 Nobel Peace Prize was awarded, the Convention on the Prohibition of the Use, Stockpiling, Production and Transfer of Anti-personnel Mines and on their Destruction was negotiated in Ottawa in December 1997. The Convention calls for a total ban on the production, transfer, and placement of antipersonnel landmines. In September 1998, when the 40th nation ratified the Convention, bringing it into force, 130 nations had signed the Convention. To its shame the United States has stated that it will not sign the treaty in its present form. In addition an enormous effort, both in money and personnel, will be required to remove the millions of landmines now implanted in the world.[68]

Doctors also have special opportunities to educate the public and political leaders about the dangers of weapons of mass destruction, as illustrated by the work of physicians in Boston in 1962 who published a widely-known series of articles in The New England Journal of Medicine on "The Medical Consequences of Nuclear War". The nuclear weapons states must honor the commitment to nuclear disarmament to which they agreed in Article VI of the 1972 Nuclear Non-Proliferation Treaty, which was reaffirmed unanimously in 1996 by the International Council of Justice.[69] The nations of the world that have not done so must be urged to ratify the Chemical Weapons Convention, the Biological Weapons Convention, and the Landmines Convention and to work for their full implementation.

\section{The Role of Civil Society}

Governments and inter-governmental bodies such as the United Nations have an extraordinarily-important role in protecting human rights and health. But many of the rich nations, especially the United States, and the international institutions they control, are much more concerned with political rights than with economic rights. When the governments of rich nations and intergovernmental bodies concentrate solely on political rights, other ways must be found to support economic rights and to support the prevention of war. In this context organizations of civil society (commonly called "non-governmental 
organizations") and individuals have vital roles to play.[70]

Organizations in every sector of society must be mobilized for this task. Members of the legal profession, for example, have formed the International Association of Lawyers Against Nuclear Arms (IALANA), which has an active group in the Netherlands. The Johannes Wier Foundation for Health and Human Rights, affiliated with Physicians for Human Rights in the United States, performs important work on these issues. The International Physicians for the Prevention of Nuclear War (IPPNW), recipient of the 1985 Nobel Peace Prize, has as its affiliate in the Netherlands the Nederlandse Vereniging voor Medische Polemologie [Dutch Medical Association for Peace Research](NVMP). The NVMP has played an important role in work for abolition of nuclear weapons. It has also made efforts to honor the work that physicians of the Netherlands have done to prevent war and to protect human rights.

An example is the NVMP recognition of the extraordinary contributions to work for peace of Dr. J.A. Verdoorn, a pioneer in the field of medische polemologie [medical peace research], by the republication in 1995 of his widelyhonored 1972 book, Arts en Oorlog [The Physician and War].[71] They have also honored the heroic contributions made by Dutch physicians who resisted measures by the occupying forces to place medicine in the Netherlands under Nazi supervision. A majority of the physicians left the Dutch Medical Association as soon as it became obvious that the Nazi Administration would control the Association. Throughout the war many Dutch physicians, working under extremely difficult conditions, organized themselves effectively to resist the measures imposed by the occupiers. In 1945 the resistance group re-established the Dutch MedicalAssociation and continued the publication of the former underground newsletter, "Medisch Contact" [Medical Contact], as its official publication.[72]

\section{The Hague Appeal for Peace}

One of the important contributions of civil society in the Netherlands is its role in the organization of the Hague Appeal for Peace, a major end-of-century campaign and conference dedicated to the de-legitimization of war and the creation of a culture of peace. The Hague Appeal for Peace Conference will complete the extraordinary sequence of world conferences held over the last decade on children, the environment, human rights, social development, pop- 
ulation, women, and habitat but with an important difference: this last major conference of this century is being convened by civil society rather than by governments. The Conference will be held in The Hague from May 11 to 15, 1999.

May 1999 marks the 100th anniversary of the First Hague International Peace Conference, called by Czar Nicholas II of Russia and the Queen of the Netherlands. It was the first time world leaders held a conference not to conclude or settle a war, but to focus on war prevention, arms control and peacebuilding measures. Initiatives leading to the formulation of international laws and institutions such as the League of Nations, precursor to the United Nations, can be traced to the 1899 efforts in The Hague.

The 1999 Hague Appeal for Peace Conference will address four specific themes:

- strengthening and expanding international human rights and humanitarian law;

- advancing the peaceful settlement of disputes, including conflict prevention and peace-building;

- devising strategies for achieving global disarmament, including nuclear abolition; and

- examining the root causes of war and developing a culture of peace for the 21 st century.

Over 600 non-governmental organizations from all sectors of civil society are supporting the Hague Appeal. Planning was initiated by IALANA, IPPNW, the International Peace Bureau, and the World Federalist Movement.

\section{Honoring the 50th Anniversary of the Universal Declaration of Human}

\section{$\underline{\text { Rights }}$}

Fifty years ago the United Nations General Assembly adopted the Universal Declaration of Human Rights (UDHR) to guarantee all human beings security, dignity, and well-being in every country of the world.[73] Although not binding in international law, the UDHR has set the foundation for dozens of international treaties and laws that protect human rights. 
Many of the human rights discussed in this lecture are guaranteed by the UDHR. Articles 1 and 2 of the UDHR, for example, state that all human beings are born equal in dignity and rights and that these rights are guaranteed to everyone without distinction. Other rights guaranteed by the UDHR include the right to: freedom from torture (Article 5); freedom of opinion and expression (Article 19); work and just and favorable conditions of work (Article 23); rest and leisure (Article 24); a standard of living adequate for the health and well-being of all people and their families, including food, clothing, housing, medical care, and necessary social services (Article 25); education (Article 26); and "a social and international order in which the rights and freedoms set forth in this Declaration can be fully realized" (Article 28).

On December 10, 1998, just two weeks from today, the world will celebrate Human Rights Day on the date of the 50th anniversary of the adoption of the UDHR. In this anniversary year everyone, and perhaps especially physicians and other health professionals, and all their institutions, and perhaps especially faculties of medicine, public health, nursing, and allied health professions, must join in increasing awareness of the connection between health and human rights. During the past decade, this awareness has led to new education and training about human rights for health professionals. Faculties of medicine, public health, and nursing have inaugurated full courses, seminars, short-courses, and sponsored conferences to advance understanding of health to protection of human rights.[74]

\section{Conclusion}

Physicians and other health workers have special knowledge of the close connection between health and human rights and of the health consequences of bigotry, of poverty, of degradation of the environment, and of militarism and war. International law is critically important, as Dean Cleveringa understood, to bring about the social and international order necessary for the realization of human rights and for the promotion and protection of health. But civil society and its institutions will have an increasingly important role to play, and health workers must be vitally involved in this development. The successful promotion of health, prevention of disease, and treatment and rehabilitation of those with disease and injury, are in large part dependent on the promotion and protection of human rights. In this anniversary year of the 
Universal Declaration of Human Rights we must re-dedicate ourselves, in the words of the United Nations Charter, "to advance and strengthen the respect of human rights for all people."

\section{Acknowledgments}

Materials from which this oration was drawn was provided by Jos Weerts and Carolus de Jong van Lier of the Nederlandse Vereniging voor Medische Polemologie [Dutch Medical Association for Peace Research], the Netherlands affiliate of the International Physicians for the Prevention of Nuclear War; Annemiek Richters, Professor of Women and Health at the Leiden University Medical Center; Harm Beukers, Professor of Metamedica at the Leiden University Medical Center; W. Hijmans, Professor at the Leiden University Medical Center; Rik Boswerger, secretary of the Board of Leiden University Medical Center; Anthony Anderson of the University of Southern California; and members of the organizations forming the Consortium for Health and Human Rights, which consists of the Francois-Xavier Bagnoud Center for Health and Human Rights, Global Lawyers and Physicians, International Physicians for the Prevention of Nuclear War, and Physicians for Human Rights. In addition, Harm Beukers, Rik Boswerger, Ann Ferrara, Thomas Hall, Annemiek Richters, Ruth Sidel, Bert Jan Vermeer, and Jos Weerts have reviewed drafts of this address. Their comments and suggestions have been deeply appreciated, but any errors of fact or controversial statements of opinion are of course my own.

Ik heb gezegd. 


\section{$\underline{\text { References }}$}

1. W. Warmbrunn, The Dutch Under German Occupation 1940-1945 (New York; Oxford University Press and Stanford University Press, 1963); J. Presser, Ashes in the Wind: The Destruction of Dutch Jewry, Translated by A. Pomerans (Detroit: Wayne State University Press, 1988); and A. Anderson, "Anne Frank Was Not Alone: Holland and the Holocaust," Lecture, University of Southern California, October 24, 1995.

2. R.P. Cleveringa, "Namens de Juridische Faculteit: Als Decaan Gehouden Naar Aanleiding Van Het Ontslag Van Prof. Mr. E.M. Meyers als Hooglerear Aan De Rijksuniversiteit Te Leiden [On Behalf of the Faculty of Law: The Obligation of the Dean on the Occasion of the Dismissal of Prof. Mr. E.M. Meyers as Professor at the State University of Leiden]," Lecture, Faculty of Law, University of Leiden, November 26, 1940.

3. J. Hendriksen and W. Hijmans, De "Rassencolleges" van Barge [The "Race Lectures" of Barge], Overdruk Leids Jaarboekje 1995 (Leiden: Vereniging Dud Leiden, 1995), pp. 194-213; W. Schrama, Het Vergeten Protest van Professor Barge [The Forgotten Protest of Professor Barge], Cicero, May 25, 1995; J. Hendriksen and W. Hijmans, The Anatomy Lessons of Professor Barge, Journal of the Royal Society of Medicine 89:649-650, 1996.

4. J.B. Charles,"26 November 1940: Prasidium Libertatis"' [Bulwark of Liberty], Vrij Nederland, 27 November 1976; W.C.S. van Rentham Jutting, "Van Holk in protest op 26 November 1940 tegen schorsing van joodse hoogleraren:'Wij voelen de maatregelen als een smaad der universiteit en ons volk aangedaan' [Van Holk in protest on 26 November 1940 against the dismissal of Jewish professors: We feel the regulations as an insult to the university and to our people], Mare, Vol. 10, 25 November 1982.

5. P.J. Idenburg, De Leidse universiteit [Leiden University] 1928-1946 (The Hague: Leiden University Press, 1978).

6. R.-J. Dupuy, ed., The Right to Health as a Human Right (Alphen aan den Rijn: Sijthoff and Noordhoff, 1979); V. Leary, The Right To Health in International Human Rights Law, Health and Human Rights 1:24-57, 1994.

7. J.M. Mann , L. Gostin, S. Gruskin,, T. Brennan, Z. Lazzarini, and H. Fineberg, Health and Human Rights, Health and Human Rights 1:6-23, 1994; Consortium for Health and Human Rights, Health and Human Rights: A Call to Action on the 50th Anniversary of the Universal Declaration of Human Rights, Journal of the American Medical Association 280:462-464, 1998. 
8. E. Pagels, The Origin of Satan (New York: Random House, 1995)

9. R.J. Hernnstein and C. Murray, The Bell Curve: Intelligence and Class Structure in American Life (New York: Free Press, 1994); R. Sidel, Keeping Women and Children Last (Revised Edition) (New York: Penguin Books, 1998).

10. R.G. Wilkinson, Unhealthy Societies: The Afflictions of Inequality (New York: Routledge, 1998).

11. R. Cooper and R. David, The Biological Concept of Race and Its Application to Public Health and Epidemiology, Journal of Health Politics, Policy and Law 11:97-116, 1986; M.T. Fullilove, Abandoning "Race" as a Variable in Public Health Research: An Idea Whose Time Has Come, American Journal of Public Health 88:1297-1298, 1998.

12. E.N. Wolff, How the Pie is Sliced: America's Growing Concentration of Wealth, The American Prospect, 22:58-64, 1995; M. Perelman, The Pathology of the U.S. Economy: The Costs of a Low-Wage System (New York: St. Martin's Press, 1996); R. Sidel, see note 9 .

13. United Nations Development Program, Human Development Report 1998 (New York: Oxford University Press, 1998).

14. K. Danaher, ed., Fifty Years is Enough: The Case Against the World Bank and International Monetary Fund (Boston: South End Press, 1994); W.I. Robinson, Promoting Polyarchy: Globalization, U.S. Intervention, and Hegemony (Cambridge: Cambridge University Press, 1996).

15. Susan George, Fate A Worse than Debt: The World Financial Crisis and the Poor (New York: Grove Press, 1988); United Nations Development Program, see note 13 , p. 100 .

16. United Nations Development Program, Human Development Report 1991 (New York: Oxford University Press, 1991), p.187; United Nations Development Program, see note 13, p.196.

17. J. Reldman, D. Makuc, J. Kleinman and J. Cornoni-Huntley, National Trends in Educational Differentials in Mortality American, Journal of Epidemiology; 129:919-933, 1989.

18. Institute of Medicine, Committee for the Study of the Future of Public Health, The Future of Public Health (Washington, DC: National Academy Press, 1988). 
19. T.A. Ziv and B. Lo, Denial of Care to Illegal Immigrants: Proposition 187 in California, New England Journal of Medicine 332:1095-1098, 1995; S. Woolhandler and D.U. Himmelstein, For Our Patients, Not For Profits (Cambridge, Mass: Center for National Health Program Studies, 1998); R. Pear, Americans Lacking Health Insurance Put at 16 Percent, New York Times, September 26, 1998.

20. A. Hendriks, A. Neufeldt and R. Mathieson, A Selected Bibliography of Human Rights and Disability, Health and Human Rights; 1:212-225, 1994; K. Tomasevski, S. Gruskin, A. Hendriks and Z. Lazzarini, AIDS and Human Rights: Patterns of Violations. In: J.M. Mann and D. Tarantola, eds., AIDS in the World (Cambridge: Harvard University Press, 1992), pp. 537-573.

21. R.J. Blendon, H. Aiken, H. Freeman and C. Corey. Access to Medical Care for Black and White Americans. Journal of the American Medical Association 261:278-281, 1989; L. Aday, At Risk in America: The Health and Health Care Needs of Vulnerable Populations in the United States (San Francisco: Jossey-Bass Inc., 1993); H.J. Geiger, Race and Health Care: An American Dilemma, New England Journal of Medicine 335:815-816, 1996; H.J. Geiger. Racism Resurgent: Building a Bridge to the 19th Century, American Journal of Public Health 87:1765-1766, 1997.

22. H.J. Geiger, Ethnic Cleansing in the Groves of Academe, American Journal of Public Health 87:730-732, 1997.

23. M. Koivusalo and E. Ollila, Making a Healthy World: Agencies, Actors and Policies in International Health (London, Zed Books, 1997).

24. C.K. Lum and S.G. Korenman, Cultural-Sensitivity Training in U.S. Medical Schools Academic Medicine 69:239-241, 1994.

25. World Bank, World Development Report 1997 (New York: Oxford University Press, 1997).

26. J. Peters and A. Wolper. Women's Rights, Human Rights: International Feminist Perspectives. (New York: Routledge, 1995); R. Cook. Gender, Health and Human Rights. Health and Human Rights 1:350-366, 1995; K. Moore, K. Randolph, N. Toubia and E. Kirberger, A Case Study Using Female Genital Mutilation: The Synergistic Relationship Between Health and Human Rights. Health and Human Rights 2:137-146, 1995; Physicians for Human Rights, The Taliban's War on Women: A Health and Human Rights Crisis in Afghanistan (Boston: Physicians for Human Rights, 1998); B. Herbert, Half a Nation Condemned: African Women's Medical Dilemma, New York Times, October 8, 1998. 
27. L. Gostin and J.M. Mann, Towards the Development of a Human Rights Impact Assessment for the Formulation and Evaluation of Public Health Policies, Human Rights and Health; 1:58-80, 1994; L. Freedman, Censorship and Manipulation of Reproductive Health Information: An Issue of Human Rights and Women's Health. In: S. Coliner, ed., The Right to Know: Human Rights and Access to Reproductive Health Information (Philadelphia: University of Pennsylvania Press, 1995), p.1-37.

28. United Nations Children's Fund, The State of the World's Children 1996 (New York: Oxford University Press, 1996).

29. United Nations Children's Fund, The State of the World's Children 1998 (New York: Oxford University Press, 1998).

30. D.L. Parker. Child Labor: The Impact of Economic Exploitation on the Health and Welfare of Children, Minnesota Medicine 80:10-13, 52-55, 1997.

31. A. Iles, Health and Environment: A Human Rights Agenda for the Future, Health and Human Rights 2: 46-61, 1995.

32. United Nations Development Program, see note 13.

33. C. Flavin and S. Dunn, Responding to the Threat of Climate Change. In: L.R. Brown, C. Flavin and H. French, eds., State of the World 1998 (New York: W.W. Norton, 1998), pp. 113-130.

34. M. Renner, Fighting for Survival: Environmental Decline, Social Conflict, and the New Age of Insecurity (New York: W.W. Norton, 1996)

35. V.S. Rezendes, Global Warming: Administration's Proposal in: Support of the Kyoto Protocol (GAO/T-RCED-98-219), (Washington D.C.: U.S. General Accounting Office, 1998)

36. V.W. Sidel, G. Shahi and B.S. Levy, The Impact of Military Activities on Development, Environment and Health. In: T. Schroyer, ed., A World That Works: Building Blocks for a Just and Sustainable World (New York: Bootstrap Press, 1997), pp. 321-336.

37. B. Bryant and P. Mohai, eds., Race and the Incidence of Environmental Health Hazards: A Time for Discourse (Boulder, CO: Westview Press, 1992); R.D. Bullard. Unequal Protection: Environmental Justice and Communities of Color (San Francisco: Sierra Club Books, 1994) 
38. United Church of Christ Commission for Racial Justice, Toxic Wastes and Race in the United States: A National Report on the Racial and Socio-Economic Characteristics of Communities Surrounding Hazardous Waste Sites (New York: United Church of Christ, 1987); V.W. Sidel, B.S. Levy and B. Johnson, Environmental Injustice: What Must Be Done?, Health and Environment Digest 9:79-80, 1996; E.M. Northridge and P.M. Shepard, Environmental Racism and Public Health, American Journal of Public Health 87:730-732, 1997.

39. V.W. Sidel and G. Shahi, The Impact of Military Activities on Development, Environment and Health. In: G. Shahi, B.S. Levy, A. Binger, T. Kjellstrom and R. Lawrence, eds., International Perspectives in Environment, Development and Health: Toward A Sustainable World (New York: Springer Publishing Company for the Rockefeller Foundation, 1997), pp. 283-312.

40. G.J. Annas and M.A. Grodin, eds., The Nazi Doctors and The Nuremberg Code: Human Rights in Human Experimentation.(New York: Oxford University Press, 1992); M.A. Grodin and G.J. Annas, Legacies of Nuremberg: Medical Ethics and Human Rights, Journal of the American Medical Association 276:1682-1683, 1996; V.W. Sidel, The Social Responsibilities of Health Professionals: Lessons from Their Role in Nazi Germany, Journal of the American Medical Association 276:1679-1681, 1996.

41. P.A. King, Twenty Years After: The Legacy of the Tuskegee Syphilis Study: The Dangers of Difference, Hastings Center Report 22:35-8, 1992; A. Yankauer, The Neglected Lesson of the Tuskegee Study, American Journal of Public Health $88: 406,1998$.

42. V.W. Sidel, Medicine and War. In: W.T. Reich, ed., Encyclopedia of Bioethics (Second Edition). (New York: Simon \& Schuster Macmillan, 1995), pp.2533-38; Advisory Committee on Human Radiation Experiments, Research Ethics and the Medical Profession, Journal of the American Medical Association 276: 404-409, 1996.

43. Resolution WHA 34.38, World Health Assembly (Geneva: World Health Organization, 1981).

44. R.M. Garfield and A.I. Neugut, The Human Consequences of War. In: B.S. Levy and V.W. Sidel, eds., War and Public Health. (New York: Oxford University Press, 1997), pp. 27-38.

45. Carnegie Commission on Preventing Deadly Conflict, Preventing Deadly Conflict: Final Report (Washington DC: Carnegie Commission on Preventing Deadly Conflict, 1997), p.3; P. Geltman and E. Stover, Genocide and the Plight of 
Children in Rwanda, Journal of the American Medical Association 277:289-294, 1997.

46. M.J. Toole and R.J. Waldman, Refugees and Displaced Persons: War, Hunger and Public Health, Journal of the American Medical Association 270:600-605, 1993; M.J. Toole, Displaced Persons and War. In: B.S. Levy and V.W. Sidel, eds., War and Public Health (New York: Oxford University Press, 1997), pp. 197-212.

47. H.J. Geiger, The Impact of War on Human Rights In: B.S. Levy and V.W. Sidel, eds., War and Public Health (New York: Oxford University Press, 1997), pp. 3950 .

48. Amnesty International, Health Personnel: Victims of Human Rights Violations (London: Amnesty International, 1991), pp 1-30; V. Iacopino, M. Heisler and R. Rosoff, Torture in Turkey and Its Unwilling Accomplices: The Scope of State Persecution and the Coercion of Physicians (Boston: Physicians for Human Rights 1996), pp.163-186.

49. S. Schwartz, ed. Atomic Audit (Washington: Brookings Institution, 1998).

50. B.S. Levy and V.W. Sidel, The Impact of Military Activities in Civilian Populations. In: B.S. Levy and V.W. Sidel, eds., War and Public Health (New York: Oxford University Press, 1997), pp. 149-167.

51. V.W. Sidel and G. Shahi, see note 39.

52. V.W. Sidel, The International Arms Trade and Its Impact on Health, British Medical Journal 311:1677-1680, 1995.

53. M. Klare, The Global Trade in Light Weapons and the International System in the Post-Cold War Era. In: J. Boutwell, M. Klare, and L Reed, eds., Lethal Commerce: The Global Trade in Small Arms and Light Weapons (Cambridge, Mass.: American Academy of Arts and Sciences, 1995), pp.31-43;

54. R.M. Coupland, ed., The SIrUS Project: Towards a Determination of Which Weapons Cause "Superfluous Injury" or "Unnecessary Suffering” (Geneva: International Committee of the Red Cross, 1997).

55. V.W. Sidel, B.P.R. Gersons and J.M.P. Weerts, Primary Prevention of Traumatic Stress Caused by War. In: R.J. Kleber, C.R. Figley and B.P.R. Gersons, eds., Beyond Trauma: Cultural and Societal Dynamics (New York: Plenum Press, 1995), pp. 277-297; N. Lewer, Conflict Resolution and Mediation for Health Professionals. In: B.S. Levy and V.W. Sidel, eds. War and Public Health (New 
York: Oxford University Press, 1997), pp. 375-387.

56. M. Renner, Keeping Peace and Preventing War: The Role of the United Nations. In: B.S. Levy and V.W. Sidel, eds. War and Public Health (New York: Oxford University Press, 1997), pp. 361-374.

57. T. W. Lippman, War Crimes Court Gives U.S. a Dilemma, Washington Post, July 22, 1998.

58. E. Stover and E.O. Nightingale, eds. The Breaking of Bodies and Minds: Torture, Psychiatric Abuse and the Health Professions. (Washington, D.C.: American Association for the Advancement of Science, 1985); A.E. Goldfeld, R.F. Mollica, B.H. Pesavento and S.V. Faraone, The Physical and Psychological Sequelae of Torture: Symptomatology and Diagnosis, Journal of the American Medical Association 259:2725-2729, 1988; Amnesty International, Amnesty International Report 1997 (New York: Amnesty International, 1997).

59. British Medical Association, Medicine Betrayed: The Participation of Doctors in Human Rights Abuses (London: Zed Books 1992); V. Iacopino, M. Heisler, S. Pishever, and R.H. Kirschner, Physician Complicity in Misrepresentation and Omission of Medical Evidence in Post-Detention Medical Examinations in Turkey, Journal of the American Medical Association 276:396-402, 1996; D. Silove, Doctors and the State: Lessons from the Biko Case, Social Science and Medicine 30:417-429, 1997.

60. Amnesty International, Prescription for Change: Health Professionals and the Exposure of Human Rights Violations (London: Amnesty International, 1996); H.J. Geiger and R.M. Cook-Deegan, The Role of Physicians in: Conflicts and Humanitarian crises, Journal of the American Medical Association 270:616-20, 1993.

61. G. R. Randall and E. L. Lutz, Serving Survivors of Torture: A Practical Manual for Health Professionals and Other Service Providers (Washington, D.C.: American Association for the Advancement of Science, 1991).

62. When Rape Becomes Genocide, New York Times, September 5, 1998, p. A10.

63. V.W. Sidel, Weapons of Mass Destruction: The Greatest Threat to Public Health, Journal of the American Medical Association 262:680-682, 1989.

64. L. Forrow, B.G. Blair, I. Helfand, G. Lewis, T. Postol, V.W. Sidel, B.S. Levy, H. Abrams and C. Cassel, Accidental Nuclear War: A Post-Cold War Assessment, New England Journal of Medicine 338:1326-1331, 1998. 
65. L. Forrow and V.W. Sidel, Medicine and Nuclear War: From Hiroshima to Mutual Assured Destruction to Abolition 2000, Journal of the American Medical Association 280:456-461, 1998.

66. Physicians for Human Rights, Winds of Death: Iraq's Use of Poison Gas Against Its Kurdish Population (Boston: Physicians for Human Rights, 1989); R.J. Smith, V.W. Sidel, M. Nass, et al., Can We Prevent the Use of Chemical Weapons by Terrorists?, Medicine and Global Survival 2:176-184, 1995; Chemical Disarmament: Basic Facts (The Hague: Organisation for the Prohibition of Chemical Weapons, 1998); V.W. Sidel, Looking Beyond the Chemical Weapons Convention Medicine and Global Survival 5:54-56, 1998.

67. Susan Wright, ed., Preventing a Biological Arms Race (Cambridge, MA: The MIT Press, 1990); R. Ekeus, Iraq's Biological Weapons Programme: UNSCOM's Experience, Memorandum Report to the United Nations Security Council, November 20, 1996; R.A. Zalinskas, Iraq's Biological Weapons: The Past As Future?, Journal of the American Medical Association 278:418-424, 1997.

68. The Arms Project of Human Rights Watch and Physicians for Human Rights, Landmines: A Deadly Legacy (New York: Human Rights Watch, 1993); International Physicians for the Prevention of Nuclear War, Landmines: A Global Health Crisis (Cambridge, MA: International Physicians for the Prevention of Nuclear War, 1997)

69. A. F. Ginger, ed., Nuclear Weapons are Illegal: The Historic Opinion of the World Court and How It Will Be Enforced. (New York: Apex Press, 1998); V.W. Sidel, The Role of Physicians in the Prevention of Nuclear War. In: B. C. Strozier and M. Flynn eds., Genocide, War, and Human Survival (Lanham, Maryland: Rowman and Littlefield Publishers, 1996), pp. 193-205.

70. R. Falk, A Half Century of Human Rights, 1998 (in press); G.A. Christenson, World Civil Society and the International Rule of Law, Human Rights Quarterly 19: 724-737, 1997; R. Falk, The World Order Between Inter-State Law and the Law of Humanity: The Role of Civil Society Institutions, In: D. Archibugi and D. Held, eds.,Cosmopolitan Democracy: An Agenda for a New World Order (Cambridge, U.K.: Polity Press, 1995), pp. 163-179; Kofi Annan, Call for New United Nations-NGO Partnership Amidst Ongoing Human Rights Revolution, UN Doc. SG/SM/6697 (New York: United Nations Office of Public Information, September 14, 1998), available at http:/www.un.org/news.

71. J.A. Verdoorn, Arts en Oorlog [The Physician and War] (Rotterdam: Erasmus Publishing, 1995). 
72. J.M.P. Weerts, Medical Contact: Dutch Physicians During the Second World War, Paper, St. Louis, Missouri, April 12, 1994.

73. Universal Declaration of Human Rights. United Nations General Assembly resolution 217 A (III), December 10, 1948. [UN document A/810 at 71 (1948)], reprinted in Journal of the American Medical Association 279:469-470, 1998.

74. J. Sonis, D.W. Gorenflo, P. Jha and C. Williams, Teaching of Human Rights in US Medical Schools. Journal of the American Medical Association; 276:1676-1678, 1996; J. Leaning, Human Rights and Medical Education. Why Every Medical Student Should Learn the Universal Declaration of Human Rights, British Medical Journal 313:1390-1391, 1997; J. Brenner, Human Rights Education in Public Health Graduate Schools, Health and Human Rights; 3:129-139, 1996; Consortium for Health and Human Rights, Health and Human Rights: A Call to Action on the 50th Anniversary of the Universal Declaration of Human Rights, Journal of the American Medical Association 280:462-464, 1998. 